\title{
CESPUC
}

\section{MANUAL DE REDAÇÃO DA PRESIDÊNCIA DA REPÚBLICA: ENTRE PRINCÍPIOS E MITOS}

\author{
Paulo Anízio Martins de Souza'
}

\begin{abstract}
Resumo
Este trabalho trata da existência de possíveis mitos linguísticos no Manual de redação da Presidência da República (MRPR), entendidos mitos linguísticos como quaisquer enunciados de natureza gramatical sujeitos a questionamentos, por ser cabível tomá-los como materialização de ideias inconsistentes sobre a língua, sobre sua variedade de maior prestígio e sobre o texto. Para isso foram cotejadas tais ideias com o posicionamento de autores da abordagem funcional e pragmática, com artigos da Constituição Federal no qual se baseia o manual de redação analisado, bem como com aspectos de ordem social e geográfica, peculiares ao território e à população brasileira, chegando-se ao que propusemos chamar de "Mito da homogeneidade do destinatário", "Mito do padrão culto de linguagem" e "Mito da clareza do texto oficial". Não se buscou invalidar o uso do padrão culto de linguagem e/ ou o cuidado com a clareza textual, senão questionar a total eficácia dessa variedade da língua na apreensão dos atos e documentos emanados do poder público, bem como os meios apresentados para o alcance de tal clareza.
\end{abstract}

Palavras-chave: Manual de redação. Mitos. Padrão culto da língua. Clareza textual.

\section{STYLE MANUAL OF THE PRESIDENCY PUBLISHING: BETWEEN PINCIPLES AND MYTHS}

The present paper focuses on the existence of possible linguistic myths in the Style Manual of the Government Publishing (Manual de Redação da Presidência da República) in which linguistic myths are conceived as any grammatical utterance to susceptible to questioning as they materialize inconsistent ideas about language, about its most prestigious variety and about texts. These notions were compared to the works of functionalist and pragmatic authors, the articles in the Federal Constitution on which the manual is based on as well as aspects of social and geographical order particular to the territory and the Brazilian population, resulting in what we named the "Myth of the Homogeneous Recipient", "Myth of the Language Standard" and "Myth of Clarity of Official Documents". Invalidating language standards and/or attention to text clarity was not an aim, but the questioning of the total efficiency of the standard variety in the understanding of facts and documents from the public sphere as well as the means used to obtain such clarity.

Keywords: style manual. Myths. Language standard. Text clarity.

Recebido em 29/05/2017 Aceito em: 19/09/2017

1 Licenciado em Letras (Língua Portuguesa), pela Universidade Federal do Pará, com especialização em Linguística e Literatura (Universidade Federal do Tocantins, 2013), e em Revisão de Textos (IEC PUC Minas, 2015). Atua como consultor legislativo / revisor de texto na Assembleia Legislativa do Estado do Tocantins desde 2006, teve experiência no magistério (Estado do Pará, 2004 e 2005). Este artigo, fruto de pesquisa de conclusão da pós de RT, foi orientado pelo Prof. Dr. Cristiano Florentino. 


\section{C \\ 2O SEMESTRE DE $2017-$ N. 31}

\section{As concepções de língua e visão formalista do MRPR}

Partindo da leitura de Wilson (2009), podemos observar duas concepções fundamentais e distintas envolvendo as questões da língua: a formalista e a funcional e pragmática.

Para a nossa abordagem, importa o contexto discursivo, os propósitos comunicativos dos interlocutores, vistos não como sujeitos teóricos, mas como sujeitos reais "inseridos em situações concretas, com papéis sociais múltiplos e diversificados” (WILSON, 2009, p. 241). Sujeitos esses que, como observa Travaglia (2009, p. 23), “ocupam lugares sociais e 'falam' e 'ouvem' desses lugares de acordo com formações imaginárias (imagens) que a sociedade estabeleceu para tais lugares sociais”. A língua é vista como um instrumento de interação social, não isolada, portanto, de sua utilização.

Nesse sentido é que Jakobson, citado por Alkmim (2007), chama a atenção para o caráter multiforme do código linguístico, que, segundo o autor, assumiria um ou outro subcódigo a depender da função da mensagem, do interlocutor ao qual a mensagem seja dirigida e das relações existentes entre este e o falante.

Por sinal, quando Jakobson defende que a homogeneidade do código linguístico "não passa de uma ficção desconcertante" (JAKOBSON apud ALKMIM, 2007, p. 25), de certa forma nos faz lembrar Bagno (2001) quando questiona o que propõe chamar de "mito da língua única":

Como é fácil deduzir, trata-se de um devaneio místico-nacionalista, puramente ideológico, que nada tem de científico. Supor que no Brasil existe uma só raça, uma só religião, uma só moral e uma só língua é levar ao paroxismo a operação intelectual característica da ideologia: a criação de universais abstratos, isto é, a transformação de ideias particulares da classe dominante em ideais universais de todos e para todos os membros da sociedade [...] (BAGNO, 2001, p. 51, grifo do autor)

Nesse particular, Patriota (2009) chega mesmo a chamar a atenção para uma possível supervalorização do padrão culto de linguagem dispensada pelos professores, a tal ponto de este ser visto como possuidor de poderes mágicos.

Tem-se, portanto, no universo dos professores, uma concepção de língua como um fetiche, um padrão a ser seguido e venerado, ao qual são atribuídas características mágicas e, como tal, deve ser zelado, cuidado, como forma de mantê-lo intacto, puro. (PATRIOTA, 2009, p. 48)

Se considerarmos a abordagem funcional e pragmática depositária dos avanços dos estudos linguísticos, discursivos, semióticos e literários, avanços esses dos quais fala Costa Val (2004) quando trata da redefinição do que se entende por texto, notamos que é a partir dessa abordagem que podemos entender o texto não apenas como produção linguística escrita e que sua extensão e seu sentido são relativos.

Assim, como produto linguístico também oral, até mesmo um "té" de uma criança pode ser classificado como texto, segundo Costa Val. E, no tocante ao sentido, como observa a 


\section{CESPUC \\ 2O SEMESTRE DE $2017-$ N. 31}

autora, ele se daria, na verdade, em função de fatores de textualidade que os interlocutores processariam a cada situação de interação. Não seria, portanto, mais cabível conceber um texto dotado de sentido e/ou de coerência por si mesmo.

Resumindo: uma produção linguística que, numa dada circunstância, pareça "sem pé nem cabeça", incompreensível, inadequada, inaceitável, para determinado grupo, pode ser perfeitamente entendida e considerada como sem qualquer problema por outros interlocutores, noutra situação, e, para eles, funcionar plenamente como texto. Isso quer dizer que o sentido não está no texto, não é dado pelo texto, mas é produzido por locutor e alocutário a cada interação, a cada "acontecimento" de uso da língua. (COSTA VAL, 2004, p. 2)

Como observa Oliveira (2009), é de uma perspectiva textual, entendida aí a da linguística textual, que constituintes de natureza adverbial ou de função relacional, como conjunções ou preposições, até então com atuação restrita no âmbito da frase ou do período na abordagem da gramática tradicional, assumem funções macrossintáticas.

No texto escrito [que a autora usa como exemplo], em termos de relações conjuntivas, um dos destaques é o uso dos sintagmas adverbiais "certo dia" e "no decorrer de sua adolescência" a iniciar, respectivamente, o primeiro e o segundo parágrafos. Na verdade, esses constituintes não fazem referência somente aos períodos em que se integram. Eles circunstancializam todo o parágrafo - é o conjunto de períodos a que se referem, numa ampliação de seu escopo, já que tradicionalmente o advérbio é considerado termo modificador de um verbo, um nome ou outro advérbio. (OLIVEIRA, 2009, p. 199)

Já na abordagem formalista, como observa Travaglia (2009), a língua é vista como código virtual, isolado de sua utilização, com propósito unicamente comunicativo. Sob esse enfoque, para que a comunicação possa se dar, basta que o código, a língua ou o conjunto de signos que a compõe seja de domínio dos falantes e com efeito devidamente combinados:

Nessa concepção a língua é vista como um código, ou seja, como um conjunto de signos que se combinam segundo regras e que é capaz de transmitir uma mensagem, informações de um emissor a um receptor. Esse código deve, portanto, ser dominado pelos falantes para que a comunicação possa ser efetivada. (TRAVAGLIA, 2009, p. 22)

Conforme Wilson (2009), questões envolvendo a análise de quem, como, quando ou para que se faz uso da língua, caras à concepção funcional e pragmática, não importam para essa perspectiva. Em outras palavras, as situações reais de comunicação, as relações entre língua e homem e entre este e seu meio social não merecem consideração sob a perspectiva formalista, como frisa a autora. Tratar-se-ia de uma visão uniforme e homogênea de língua, como se percebe a seguir:

Lidar com o fenômeno linguístico nessa perspectiva é tratá-lo de modo abstrato, considerando-o objeto único de investigação. De acordo com tal perspectiva, não importa à análise quem, como, quando ou para que (se) faz uso da língua, uma vez que o que está no foco da atenção é tão somente a própria estrutura linguística, de certa forma deslocada de todas as interferências comunicativas que cercam sua produção e recepção. (WILSON, 2009, p. 236, grifos da autora) 


\section{CESPUC}

É com essa visão de língua que o MRPR parece tentar oferecer aos seus consulentes orientações de como elaborar os atos e expedientes oficiais, (re)produzindo, no entanto, ideias que, se postas à luz da abordagem funcional e pragmática, acreditamos que podemos entender como fantasiosas, sugestivas dos mitos que procuramos apresentar.

Obediente à abordagem formalista de língua, pode-se encontrar no MRPR um tratamento gramatical semelhante ao dado em obras como a de, citando apenas os autores mais conhecidos, Evanildo Bechara, Domingos Paschoal Cegalla, Celso Cunha, Lindley Cintra, Ulisses Infante e Celso Pedro Luft. Semelhante, porque não parece haver o devido aprofundamento, observado nas gramáticas normativas, o que, segundo Bagno (2001), as diferenciaria de publicações como as dos manuais de redação em geral, entendidos, na terminologia do autor, como uma das formas de manifestação dos "comandos paragramaticais".

Mostras dessa semelhança dão-nos a impressão de serem bastante frequentes. Senão vejamos.

A parte voltada para as questões estritamente linguísticas do Manual apresenta 72 páginas distribuídas nos seguintes capítulos:

Capítulo I - Aspectos gerais da redação oficial, com 4 das 72 páginas;

Capítulo II - As comunicações oficiais, com 20 das 72 páginas;

Capítulo III - Elementos de ortografia e gramática, com 48 das 72 páginas.

Em tais capítulos, de forma geral, chama-nos a atenção o fato de a ambiguidade (p. 52) ser tratada na parte de sintaxe, não de semântica, e a parte que seria de semântica (p. 64-70) restringir-se a listas de homônimos e parônimos e de expressões a evitar, ao lado de outras de uso recomendável. Aspectos esses que parecem reforçar o tom formalista da obra, enquanto que as expressões a evitar e de uso recomendável parecem evidenciar sua característica bagniana de "comando paragramatical".

Embora o Capítulo I fale de impessoalidade, em nenhum momento trata dos recursos para alcançá-la, como o uso de modalizadores e de formas impessoais, a saber, voz passiva, sujeito indeterminado, etc. Situação análoga se dá quando o mesmo capítulo trata da clareza dos textos oficiais, não trazendo à baila em nenhum momento noções de coerência e coesão textuais, fatores de textualidade esses que nos parecem elementares para o desenvolvimento do assunto.

Será nesse capítulo em particular do MRPR que procuraremos identificar as possíveis ideias fantasiosas que nos sugerem a existência de mitos, seja em torno do tratamento dispensado à clareza textual, seja em torno do tratamento dispensado ao padrão culto de linguagem, visto como eficaz entre cidadãos e outros destinatários supostamente homogêneos. 


\section{Mito da homogeneidade do destinatário': o apagamento das diferenças}

O MRPR apresenta como os envolvidos nas comunicações oficiais o serviço público ou o conjunto de cidadãos, com a orientação de que eles sejam entendidos de forma homogênea e assim tratados. Senão vejamos:

Percebe-se, assim, que o tratamento impessoal que deve ser dado aos assuntos que constam das comunicações oficiais decorre:

$[\ldots]$

b) da impessoalidade de quem recebe a comunicação, com duas possibilidades: ela pode ser dirigida a um cidadão, sempre concebido como público, ou a outro órgão público. Nos dois casos, temos um destinatário concebido de forma homogênea e impessoal. (BRASIL, 2002, p. 4, grifos nossos)

Como as prescrições do Manual atentam sobretudo para aspectos legais, se recorrermos à Constituição Federal, mais especificamente ao art. 84, que trata da competência privativa do Presidente da República, e mesmo ao art. 37, utilizado pelo Manual para justificar os princípios da redação oficial, é possível notar muitos outros potenciais destinatários da comunicação oficial, como empresas privadas, forças estrangeiras, outros países, etc. Tendo os artigos constitucionais mencionados como referência, como seria possível sustentar-se, então, esse tratamento homogêneo?

Ainda que nos atenhamos apenas aos órgãos públicos como recebedores da comunicação oficial, parece relevante considerar que diversos são os Poderes envolvidos, várias são as naturezas jurídicas dos órgãos públicos, alguns de direito público, outros de direito privado, e, no aspecto político-administrativo, diversos são os interesses.

Uma consulta a publicações destinadas à redação oficial e a questões da língua também parece por em xeque a prescrição de se conceber o receptor homogêneo. O próprio Manual parece apontar, ainda que incidentalmente, para certa diversidade, quando se refere à possibilidade de a comunicação oficial envolver Ministério, Secretaria, Departamento, Divisão, Serviço, Seção e/ou outro órgão público, do Executivo ou dos outros Poderes da União. Vejamos:

No caso da redação oficial, quem comunica é sempre o Serviço Público (este ou aquele Ministério, Secretaria, Departamento, Divisão, Serviço, Seção); o que se comunica é sempre algum assunto relativo às atribuições do órgão que comunica; o destinatário dessa comunicação ou é o público, o conjunto de cidadãos, ou outro órgão público, do Executivo ou dos outros Poderes da União. (BRASIL, 2002, p. 4, grifos nossos)

Menezes (1989), em obra organizada por Celso Pedro Luft, já indicava também uma diversidade dos envolvidos na troca de correspondências e atos oficiais:

1 Parece-nos oportuno eleger o termo "destinatário" principalmente por ser de extrema recorrência no MRPR. A opção pelo termo "alocutário" pareceu-nos inadequada, tanto pela abordagem formalista da obra, quanto pelo fato de ao longo dos capítulos objeto de nossa análise não termos encontrado um tratamento dispensado que remetesse ao que Costa Val (2004, p. 1) observa como "participação ativa de interação verbal". Ainda procurando seguir o apresentado pelo MRPR, faremos uso também de termos como "receptor" e "recebedor". 


\section{CESPUC \\ 20 SEMESTRE DE $2017-$ N. 31}

\section{Paulo Anízio martins de Souza}

Usualmente, divide-se a correspondência em:

$[\ldots]$

c) Oficial: quando provém de instituições do serviço público, tanto civis como militares, ou a elas se dirige. Abrange atos dos poderes legislativo, executivo e judiciário, requerimentos dos cidadãos, avisos à população, etc. (MENEZES, 1989, p. 502, grifos nossos)

Martins e Zilberknop (2002) também parecem seguir a mesma orientação, pois, a julgar pela apresentação de uma tipologia dos entes públicos e de suas esferas, as autoras consideram a administração pública, de certa forma, heterogênea:

\subsection{2 - Correspondência oficial}

Correspondência oficial é a que ocorre entre órgãos da administração direta ou indireta do serviço público civil ou militar, no âmbito municipal, estadual ou federal. (MARTINS \& ZILBERKNOP, 2002, p. 147, grifo nosso)

Saindo do estritamente administrativo, das chamadas pessoas jurídicas, e voltando-se para as pessoas físicas, um olhar funcional e pragmático de língua sobre a figura do receptor nos faz considerar que, na verdade, o que há são sujeitos reais em situações concretas, ocupantes de lugares sociais de onde falam e ouvem, como expõe Travaglia (2009). Longe, portanto, da anunciada homogeneidade do MRPR.

Nesse particular, Azeredo (2008) tece comentário que acreditamos pertinente reproduzir:

Também é verdade, porém, que nenhuma comunidade, por menor que seja, é cem por cento homogênea: seus membros se distinguem pelos papéis que desempenham, pelas tarefas que lhes são destinadas ou que eles assumem por livre escolha. (AZEREDO, 2008, p. 56-57)

Isso não deixa de lembrar Wilson (2009, p. 241), quando a autora fala de sujeitos reais com "papéis múltiplos e diversificados".

Diante do observado e considerando as idiossincrasias do País, parece-nos oportuno perguntar: como podemos tratar e/ou conceber o recebedor dos atos e comunicações oficiais homogêneo, se a realidade brasileira se espraia por um território de dimensões continentais, nos mais diferentes espectros de costumes e de posições sociais? Não teríamos aí, nessa realidade multifacetada, a mais forte evidência do mito que procuramos apresentar? Ou não teríamos aí ainda um exemplo do "devaneio místico-nacionalista" trazido por Bagno (2001) quando esse autor fala do "mito da língua única"?

A charge da figura 1 a seguir parece nos ajudar a responder a tais questionamentos. Ela tenta retratar, ao que parece, um pronunciamento de uma autoridade pública que se dirige à população. Enquanto há a impressão de que os mais abastados recebem o pronunciamento de forma despreocupada e cercada de todo um conforto, alguns aparentam recebê-lo de forma apreensiva. Outros nem mesmo uma TV parecem ter e acompanham a transmissão, literalmente, no "olho da rua". Porém, sob o vocativo uniformizador, escamoteiam-se, possivelmente, realidades socioeconômicas distintas de um povo que acaba sendo tratado como se tivesse uma única composição. 
Figura 1 - Vocativo uniformizador
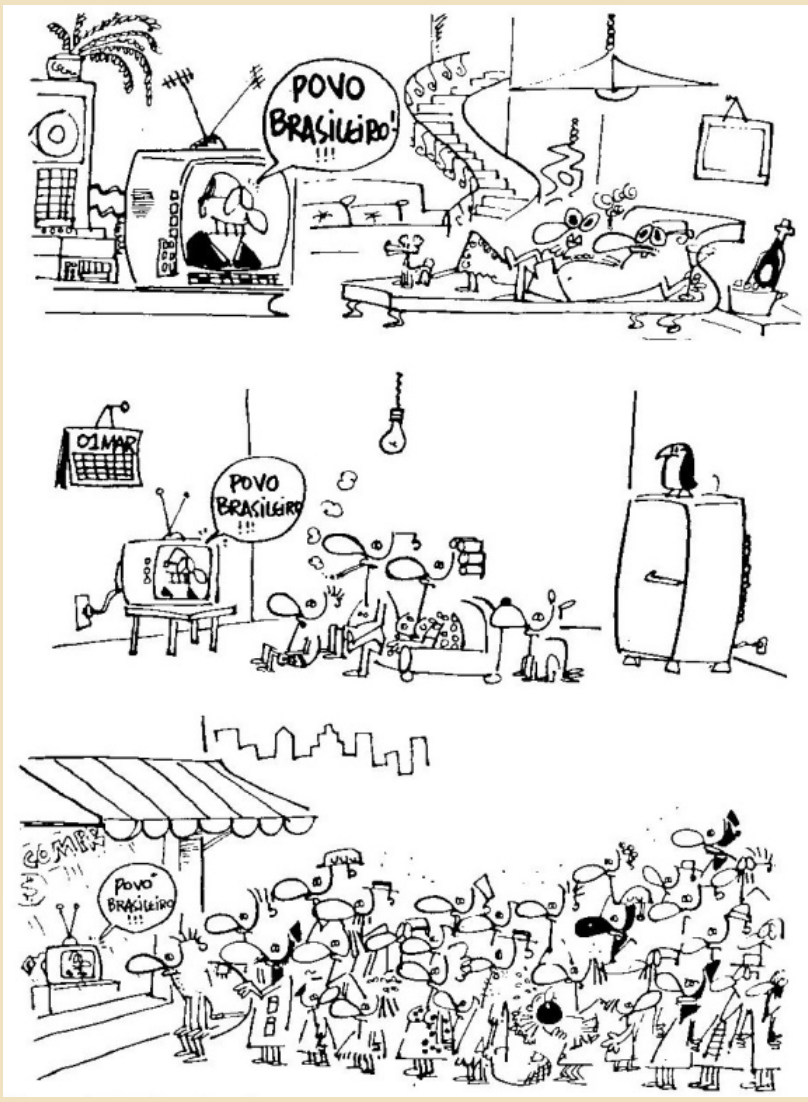

Fonte: ARANHA, 1989, p. 69

Ao questionar a suposta homogeneidade orientada pelo Manual, não estamos, todavia, adentrando no mérito do tratamento impessoal e objetivo dos atos e das comunicações oficiais, muito menos propugnando pela falta de zelo para com esse tratamento em especial. Talvez o que devesse ocorrer ao MRPR, cremos, seria assumir a diversidade dos envolvidos na comunicação oficial, porém, e por isso mesmo, alertando para possíveis mecanismos garantidores da impessoalidade, como o uso de modalizadores, da voz passiva, de indeterminação do sujeito. Mecanismos, como notamos anteriormente, sobre os quais o Manual não se pronuncia.

\section{Mito da eficácia do padrão culto de linguagem: o código linguístico como garantia de entendimento}

Se parece possível questionar a concepção homogênea do recebedor das comunicações e atos oficiais, o que dizer, então, de um código linguístico pretensamente eficaz, garantidor do entendimento dessas mesmas comunicações e atos oficiais? É o que tentaremos responder com o Mito da eficácia do padrão culto de linguagem.

Como vimos, para a abordagem formalista de língua, esta seria um código infenso às interferências sociais. Visão à qual o MRPR dá mostras de aderir com o valor que confere ao padrão culto de linguagem ou, antes, a uma pretensa eficácia que atribui a ele na apreensão do informado pela administração pública. 


\section{CESPUC \\ 20 SEMESTRE DE $2017-$ N. 31}

(2009):

Lembremos, contudo, a descrição do processo de decodificação exposto por Travaglia

Para essa concepção o falante tem em sua mente uma mensagem a transmitir a um ouvinte, ou seja, informações que quer que cheguem ao outro. Para isso ele a coloca em código (codificação) e a remete para o outro através de um canal (ondas sonoras ou luminosas). O outro recebe os sinais codificados e os transforma de novo em mensagem (informação). É a decodificação. (TRAVAGLIA, 2009, p. 22-23, grifos nossos)

Substituindo, na citação, os termos "falante", "ouvinte" e "código" respectivamente por "administração pública", "cidadão" e "padrão culto de linguagem", acreditamos que podemos ter uma descrição do que o Manual parece defender com o suposto poderio do código linguístico de per si. O que colide, porém, com o exposto por Perini (2002):

$\mathrm{O}$ ato de compreender o que nos dizem não se resume, nem de longe, ao uso correto e eficiente da língua. Portanto, para que haja comunicação é preciso que os interlocutores tenham em comum muito mais do que o conhecimento da mesma língua: é necessário que compartilhem grandes fatias do conhecimento do mundo em geral. (PERINI, 2002, p. 67)

E parece colidir até mesmo com o próprio MRPR, que chega a chamar a atenção, ainda que de forma periférica, para algo mais que o cuidado com emprego da padrão culto de linguagem.

Na revisão de um expediente, deve-se avaliar, ainda, se ele será de fácil compreensão por seu destinatário. O que nos parece óbvio pode ser desconhecido por terceiros. O domínio que adquirimos sobre certos assuntos em decorrência de nossa experiência profissional muitas vezes faz com que os tomemos como de conhecimento geral, o que nem sempre é verdade. (BRASIL, 2002, p. 6, grifo nosso)

Observamos, no entanto, que o suposto poderio do código linguístico de per si dá mostras de revelar-se principalmente quando o Manual sustenta que os propósitos dos expedientes e atos oficiais têm, no emprego do padrão culto de linguagem, total garantia. Senão como explicar o emprego do advérbio só seguido da oração subordinada adverbial condicional na passagem a seguir?

Os atos oficiais, aqui entendidos como atos de caráter normativo, ou estabelecem regras para a conduta dos cidadãos, ou regulam o funcionamento dos órgãos públicos, o que só é alcançado se em sua elaboração for empregada a linguagem adequada. O mesmo se dá com os expedientes oficiais, cuja finalidade precípua é a de informar com clareza e objetividade. (BRASIL, 2002, p. 5, grifo nosso)

Se utilizarmos a citação de Patriota, substituindo "no universo dos professores" por "no universo do MRPR", parece ser possível notar que, por trás desse advérbio e dessa oração, podemos entender até mesmo um poder mágico atribuído ao padrão culto de linguagem pelo Manual. Afirma Patriota: 


\section{CESPUC}

Tem-se, portanto, no universo dos professores, uma concepção de língua como um fetiche, um padrão a ser seguido e venerado, ao qual são atribuídas características mágicas e, como tal, deve ser zelado, cuidado, como forma de mantê-lo intacto, puro. (PATRIOTA, 2009, p. 48, grifo nosso)

Esse poder mágico conferido ao padrão culto de linguagem pode ser posto à prova quando perguntamos: será apenas o uso do padrão culto de linguagem determinante para sua obediência e/ou entendimento? O que dizer, então, das inúmeras situações litigiosas, cujas pendengas e pendências se arrastam de um tribunal a outro, a depender, na verdade, da interpretação dos juízes que se debruçam sobre textos, em princípio, "bem" escritos? O que dizer mesmo das súmulas vinculantes, que não têm outro propósito senão evitar um grande afluxo de interpretações?

Cagliari parece nos acompanhar nessas indagações:

A sociedade é regida por leis públicas que todo cidadão deve conhecer. Acontece, porém, que as leis são escritas numa linguagem que nem todo cidadão consegue entender. E, para quem entende, elas dão margem a interpretações várias, pois, embora escritas numa linguagem convencional, esta não é óbvia, não é explícita de maneira absoluta. (CAGLIARI, 2003, p. 80)

Se, de uma instância a outra, é possível dizer que não unicamente do uso do padrão culto de linguagem depende a sorte de reclamantes e reclamados, o que dizer, então, de que exclusivamente do seu uso dependeria o entendimento do cidadão a que se dirige a administração pública com os demais expedientes oficiais? Leite (2008) parece nos auxiliar na resposta:

[...] nos países em que todos (ou a maioria, pelo menos) os habitantes passam por escolas eficientes, a tradição da língua praticada é mais conhecida e fica, assim, à disposição dos falantes [...] No entanto, a realidade brasileira é bem diferente: grande parte da população não tem acesso à escola. E o problema não é só esse, porque a minoria escolarizada está dividida entre os que tiveram acesso a uma boa (ou regular) escola e os que tiveram uma escola ruim, que nem mesmo souberam manejar esse aparelho de referência da tradição. (LEITE, 2008, p. 57- 58, grifo da autora)

Se tivermos em conta que, com "tradição da língua praticada" e "aparelho de referência da tradição", a autora esteja se referindo ao padrão culto de linguagem, parecemos ter mais uma evidência do mito do MRPR que estamos procurando desvelar. E arriscaríamos dizer, numa tentativa de responder à pergunta proposta, que, a depender "só" do padrão culto de linguagem, o entendimento dos expedientes emanados da administração pública pode encontrar-se, na verdade, comprometido em um país como o Brasil, sem qualquer possibilidade de sair, do ilusionismo de Patriota (2009), digamos, um coelho da cartola. Ao falar do que chama dos "sem-língua”, endossamos nesse juízo a Bagno (2009):

[...] os falantes das variedades linguísticas estigmatizadas têm sérias dificuldades em compreender as mensagens enviadas para eles pelo poder público, que se serve exclusivamente da norma-padrão [...] Muitas vezes, os falantes das variantes estigmatizadas deixam de usufruir diversos serviços a que têm direito simplesmente por não compreenderem a linguagem empregada pelos órgãos públicos. (BAGNO, 2009, p. 30- 31) 


\section{CESPUC \\ 20 SEMESTRE DE $2017-$ N. 31}

Tal qual ocorreu na descrição do mito anterior, chama-nos a atenção mais uma vez um possível apagamento das diversidades pelo MRPR, sejam elas administrativas, jurídicas ou sociais, agora se baseando em um pretensa eficiência do código linguístico. Código linguístico esse do qual, parece-nos cabível lembrar, não ignoramos a importância, mormente no poder público. Nossa intenção foi tão somente a de contestar uma suposta eficácia desse código linguístico, principalmente quando levamos em conta as vicissitudes da vida de considerável parte da população.

\section{Mito da clareza do texto oficial: do uso eficaz do padrão culto de linguagem à interpretação única}

Vejamos como o MRPR define um texto claro:

Pode-se definir como claro aquele texto que possibilita imediata compreensão pelo leitor. No entanto a clareza não é algo que se atinja por si só: ela depende estritamente das demais características da redação oficial. (BRASIL, 2002, p. 6, grifos nossos)

Como podemos ver, as características das quais dependeria a clareza dos atos e comunicações oficiais seriam, segundo o Manual, "estritamente" a impessoalidade, o uso do padrão culto de linguagem, a formalidade e a padronização e a concisão. Características essas que acabam, em essência, por remeter, conforme podemos observar ao darmos seguimento à leitura do texto transcrito, exatamente às ideias que povoam os mitos até aqui observados: o da homogeneidade do destinatário, com a anunciada não duplicidade de interpretações, e o da eficácia do padrão culto de linguagem, supostamente de entendimento geral. Vejamos:

a) a impessoalidade, que evita a duplicidade de interpretações que poderia decorrer de um tratamento personalista dado ao texto;

b) o uso do padrão culto de linguagem, em princípio, de entendimento geral e por definição avesso a vocábulos de circulação restrita, como a gíria e o jargão;

$[\ldots]$

(BRASIL, 2002, p. 6, grifos nossos)

Como o assunto nos faz lembrar os chamados fatores de textualidade de Beaugrande e Dressler citados por Costa Val (2000, p. 38) ou mesmo dos mecanismos básicos de coesão textual de Halliday e Hasan citados por Oliveira (2009, p. 195-203), um questionamento que nos parece necessário fazer, pois determinante, a nosso ver, na identificação do mito, dá-se em torno do fato de o Manual limitar-se às características da redação oficial arroladas como as únicas concorrentes para a clareza do texto oficial. Senão, como explicar o constituinte adverbial "estritamente"? Situação semelhante vimos com o uso do advérbio "só" e da oração subordinada adverbial condicional, ambos dando mostras de superestimar o uso do padrão culto de linguagem no outro mito apresentado. 
Importante também na identificação do mito da clareza do texto oficial nos parece ser a decantada "imediata compreensão do leitor" dos atos e comunicações oficiais. Se vale aqui o que observamos com Bagno (2009), Cagliari (2003), Leite (2008), Patriota (2009), no tocante à compreensão desse texto oficial por parte dos magistrados e dos cidadãos, ou, antes, às intempéries que a envolvem, parece-nos relevante novamente mencionar que o texto, sob o enfoque funcional e pragmático, tendo a linguística textual como credora, deixou de ser visto como dotado de significado em si mesmo. Como expõe Costa Val: "O sentido não está no texto, não é dado pelo texto, mas é produzido por locutor e alocutário a cada interação, a cada 'acontecimento' de uso da língua" (COSTA VAL, 2004, p. 2). Ou como diz a metáfora de Beaugrande citada por Costa Val em outro artigo:

[...] a sequência de sons que nós realmente ouvimos ou lemos é como a ponta de um iceberg - uma pequena porção da matéria e da energia dentro da qual uma enorme quantidade de informação foi 'condensada' por um falante ou escritor e está pronta para ser 'amplificada' por um ouvinte ou leitor. (BEAUGRANDE apud COSTA VAL, 2000, p. 46-47)

Oportuno se faz esclarecer que não estamos defendendo uma falta de cuidado para com a clareza do texto oficial. Muito pelo contrário. Nosso propósito não é outro senão chamar a atenção para uma provável forma fantasiosa de o MRPR tratá-la, seja quando parece presumir um destinatário homogêneo, sempre (sub)entendido pelo Manual como dotado de informações e escolaridade suficientes para a apreensão dos atos e comunicações oficiais, seja quando parte apenas das características da redação oficial que elenca para o alcance dessa clareza.

Reforçamos, na parte que trata da clareza do texto oficial, a coesão e a coerência textuais, entendidas como cuidados caros à elaboração de textos, não são sequer mencionadas pelo Manual. Este, por sinal, como já procuramos alertar, trata da ambiguidade na sintaxe, mas não na parte dedicada à semântica, e limita esta a listas de homônimos e parônimos. Lembremos ainda que, como também observamos, embora o Manual defenda a impessoalidade, não é por ele tratado, em momento algum, o uso dos modalizadores e das formas impessoais para o seu alcance, acabando por deixar passar orientações pertinentes, e quiçá realistas, diante das diversidades. Como dissemos, seria uma forma de ele assumir a heterogeneidade dos envolvidos na comunicação oficial, alertando para possíveis mecanismos garantidores da impessoalidade.

Diante de tudo que procuramos destacar, parece-nos possível tomar os três mitos dentro de uma certa mecânica, de tal forma assim em funcionamento: 1) a redação oficial teria clareza porque não haveria "duplicidade de interpretações", com os heterogêneos tratados como homogêneos, e porque, sendo todos "iguais", 2) haveria o uso eficiente do padrão culto de linguagem. A figura 2 a seguir parece ilustrativa dessa mecânica 


\section{CESPUC

Figura 2 - Possível mecânica dos mitos apresentados

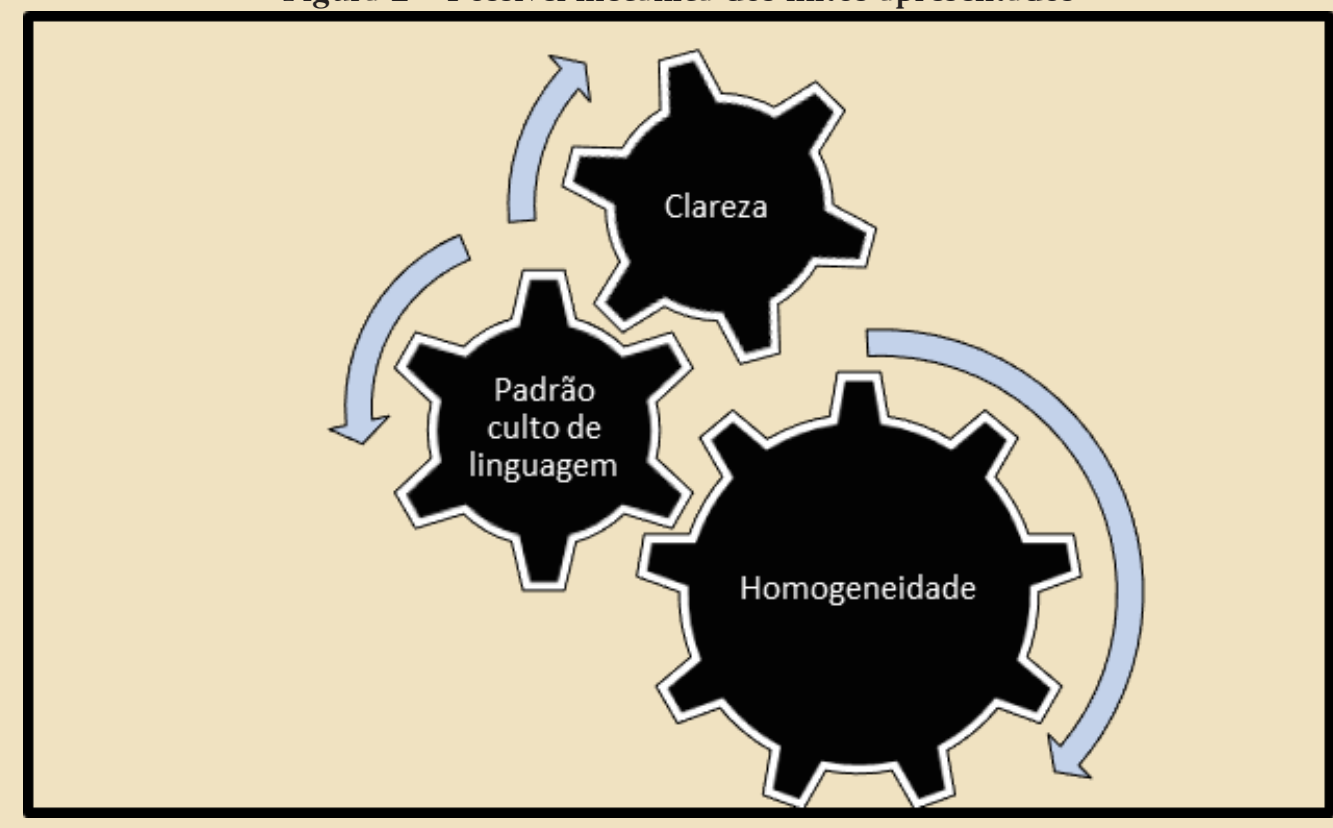

Fonte: Elaborada pelo autor.

Dizendo de outra maneira: pelo que pudemos depreender do Manual, só nos parece possível admitir uma eficácia do código (mito da eficácia do padrão culto de linguagem), se esse código for por todos compartilhado (mito da homogeneidade do destinatário), o que implicaria uma certa uniformidade entre os cidadãos e um entendimento cristalino dos atos e expedientes oficiais (mito da clareza do texto oficial).

Acontece, contudo, que, para, digamos, essa mecânica funcionar, suas engrenagens haveriam de estar em harmoniosa rotação, a ponto de o que soa duvidoso, com palavras como "homogeneidade" e "uniformidade", soasse verdadeiramente democrático, ou democraticamente verdadeiro, com palavras como "heterogeneidade", "respeito às diferenças", "igualdade", "inclusão", "empoderamento", "escolarização", tendo uma poderosa polia acoplada à estrutura como um todo: a da justiça social.

\section{Considerações finais}

Em um primeiro momento, procuramos situar o MRPR em uma concepção formalista de língua, tanto para observar que ele a trata como dotada unicamente de propósito comunicativo, quanto para observar que ele atribui a ela um tratamento homogeneizante e normativo de gramática tradicional, no qual o padrão culto de linguagem assume uma pretensa eficácia porque supostamente homogêneo também o público a que se dirigem os atos e as comunicações oficiais.

Exposto o que o Manual parece entender por língua e por envolvidos na comunicação oficial, partimos, então, para o momento central de nosso trabalho, que foi o de procurar desvelar os possíveis mitos linguísticos da homogeneidade do destinatário, da eficácia do padrão culto de linguagem e da clareza do texto oficial. 


\section{CESPUC}

No deslinde do mito da homogeneidade do destinatário, procuramos chamar a atenção para o fato de que, para o MRPR, o que existem são antes destinatários, receptores e/ou recebedores, e não "alocutários", mesmo que os atos e as comunicações oficiais envolvam sujeitos reais, sejam eles pessoas físicas ou jurídicas e sejam essas pessoas físicas ou jurídicas ocupantes das mais variadas posições sociais e/ou de poder.

No desmascaramento do mito da eficácia do padrão culto de linguagem, pareceu-nos de suma importância considerar os trâmites do meio jurídico, onde o emprego do padrão culto de linguagem não deixa de impedir que textos escritos com alto grau de monitoramento sofram interpretações várias.

Já quanto ao mito da clareza do texto oficial, pareceu-nos que poderíamos desvelálo principalmente a partir do fato de o Manual considerar que, para serem claros, os atos e expedientes oficiais devem obedecer estritamente às características de redação oficial que arrola, apesar de nada mencionar a respeito da coesão e coerência textuais e dos fatores de textualidade, noções que se mostram a nós imprescindíveis ao tema.

Para o desnudamento de todos os mitos, procuramos chamar a atenção para questões peculiares à extensão do país e às características do seu povo, notadamente socioeducacionais, características essas que, se evidenciam a heterogeneidade, evidenciam também obstáculos na apreensão dos textos emanados do poder público, justamente por fazer uso de uma variedade da língua a que boa parte da população não tem acesso adequado.

Ao chegarmos ao final do nosso trabalho, observamos a estreita ligação que os mitos que apresentamos parecem guardar entre si a ponto de nos fazer lembrar uma estrutura cujas engrenagens (padrão culto de linguagem, homogeneidade do destinatário e clareza do texto oficial) presumidamente se comunicam, porque falaciosas, já que seriam justamente as características de ordem socioeducacionais que, ao nosso ver, comprometeriam a suposta rotação harmônica entre tais engrenagens, desmentindo-as.

Cabe lembrar que, dos três capítulos do MRPR que tratam das questões linguísticas, debruçamo-nos apenas no capítulo I, com a suspeita óbvia de que haveria muito o que observar, não só nesse capítulo como nos demais. Apenas o trato que o Manual dispensa à semântica $\mathrm{e}$ à ambiguidade, manietando-as à sintaxe e a listas de caráter prescritivo e proscritivo, como observamos en passant nas páginas iniciais, já parece comprovar tal suspeita e nos deixa com a sensação de que muito mais poderia ter sido objeto de nossa atenção.

Não menos óbvia foi a suspeita de que, em manuais como o analisado, há muito que se aplicar da abordagem funcional e pragmática de língua, contrastiva da abordagem formalista que neles ainda parece imperar, o que também parece nos convidar para um aprofundamento do que tratamos e/ou para novos trabalhos.

Como frisamos ao longo da exposição dos mitos, e nos parece válido repetir, não foi nosso intento desmerecer o padrão culto de linguagem, tampouco o cuidado com a clareza do texto oficial, senão fazer notar que devem ser considerados de forma realista, para, dessa forma, 


\section{CESPUC

quem sabe, o povo seja não só mero destinatário do que é deliberado nas mais altas esferas de poder, mas partícipe de decisões que possam ser consideradas de um poder verdadeira e democraticamente público.

\section{Referências}

ALKMIM, Tânia Maria. Sociolinguística. In: MUSSALIM, Fernanda; BENTES, Anna Christina (Org.). Introdução à linguística: domínios e fronteiras. 7. ed. São Paulo: Cortez, 2007.

ARANHA, Maria Lúcia de Arruda; MARTINS, Maria Helena Pires. Filosofando: introdução à filosofia. São Paulo: Moderna, 1989.

AZEREDO, José Carlos de. Gramática Houaiss da língua portuguesa. 2. ed. São Paulo: Publifolha, 2008.

BAGNO, Marcos. Dramática da língua portuguesa. 2. ed. São Paulo: Loyola, 2001.

BAGNO, Marcos. Preconceito linguístico - o que é, como se faz. 52. ed. São Paulo: Loyola, 2009.

BRASIL. Constituição (1988) Constituição da República Federativa do Brasil. Disponível em: <http://www.planalto.gov.br/ccivil_03/constituicao/constituicao.htm>. Acesso em: 20 jan. 2015.

BRASIL. Presidência da República. Manual de redação da Presidência da República. Gilmar Ferreira Mendes e Nestor José Forster Júnior. 2. ed. rev. e atual. Brasília: Presidência da República, 2002. Disponível em: <http://www.planalto.gov.br/ccivil_03/manual/ManualRedPR2aEd. PDF $>$. Acesso em: 01 mar. 2015

CAGLIARI, Luiz Carlos. Alfabetização \& linguística. 10. ed. São Paulo: Scipione, 2003.

COSTA VAL, Maria da Graça. Repensando a textualidade. In: AZEREDO, José Carlos (Org.). Língua Portuguesa em Debate: conhecimento e ensino. Petrópolis: Vozes, 2000. p. 34-51. Disponível em: < http : // www . aedi . ufpa . br / parfor / letras / images / documentos / ativ a - dist - jan - fev2014 / BELEM / belem - 2013 -A/repensando\%20a\%20textualidade.pdf > . Acesso em: 01 mar. 2015.

COSTA VAL, Maria da Graça. Texto, textualidade e textualização. IN: CECCANTINI, J.L. Tápias; PEREIRA, Rony F.; ZANCHETTA JR., Juvenal. Pedagogia Cidadã: cadernos de formação: Língua Portuguesa. v. 1. São Paulo: UNESP, Pró-Reitoria de Graduação, 2004. p. 113-128. Disponível em <http://ead10.virtual.pucminas.br/moodle/pluginfile.php/71689/ mod_resource/content/1/Texto\%2C\%20textualidade\%2C\%20textualiza\%C3\%A7\%C3\%A3o. pdf $>$. Acesso em: 01 mar. 2015. 
LEITE, Marli Quadros. Preconceito e intolerância na linguagem. São Paulo: Contexto, 2008. MARTINS, Dileta Silveira; ZILBERKNOP, Lúbia Seliar. Português instrumental. 23. ed. rev. e ampl. Porto Alegra: Editora Sagra Luzzato, 2002.

MENEZES, João Alfredo. Correspondência comercial e oficial. In: LUFT, Celso Pedro (Org.). Novo manual de português: gramática, ortografia oficial, literatura, textos e testes. 7. ed. São Paulo: Globo, 1989.

OLIVEIRA, Mariângela Rios de. Linguística textual. In: MARTELOTTA, Mário Eduardo (Org.). Manual de linguística. São Paulo: Contexto, 2009.

PATRIOTA, Luciene Maria. A gíria comum na interação em sala de aula. São Paulo, 2009.

PERINI, Mário A. Sofrendo a gramática. 3. ed. São Paulo: Ática, 2002.

TRAVAGLIA, Luiz Carlos. Gramática e interação: uma proposta para o ensino de gramática. 13. ed. São Paulo: Cortez, 2009.

WILSON, Victoria. Linguística e ensino. In: MARTELOTTA, Mário Eduardo (Org.). Manual de linguística. São Paulo: Contexto, 2009. 